\title{
Case Report \\ Synovial Sarcoma of the Larynx: Report of a Case and Review of Literature
}

\author{
Geetha Narayanan, ${ }^{1}$ Anto Baby, ${ }^{2}$ Thara Somanathan, ${ }^{3}$ and Sreedevi Konoth ${ }^{4}$ \\ ${ }^{1}$ Department of Medical Oncology, Regional Cancer Centre, Trivandrum 695011, India \\ ${ }^{2}$ St. Gregorios Medical Mission Hospital, Parumala, Pathanamthitta 689626, India \\ ${ }^{3}$ Department of Pathology, Regional Cancer Centre, Trivandrum 695011, India \\ ${ }^{4}$ Department of Radiology, Lourdes Hospital, Kochi 682012, India \\ Correspondence should be addressed to Geetha Narayanan; geenarayanan@yahoo.com
}

Received 20 July 2016; Revised 23 October 2016; Accepted 20 December 2016; Published 9 February 2017

Academic Editor: Marco Berlucchi

Copyright (C) 2017 Geetha Narayanan et al. This is an open access article distributed under the Creative Commons Attribution License, which permits unrestricted use, distribution, and reproduction in any medium, provided the original work is properly cited.

Sarcomas account for less than $1 \%$ of malignant neoplasms arising in the head and neck in adults. Laryngeal synovial sarcoma is an extremely rare form of laryngeal malignancy with less than 20 cases reported in the literature. We report the case of a 48-year-old man with synovial sarcoma of the larynx. He underwent excision of the tumor followed by radiation. He is alive in remission at 36 months. The literature on synovial sarcoma of the larynx is reviewed.

\section{Introduction}

Sarcomas account for less than $1 \%$ of malignant neoplasms arising in the head and neck in adults and less than 5\% of soft tissue sarcomas in adults occur in the head and neck region [1-3]. Larynx is a rare primary site in which sarcomas comprise less than $1 \%$ of all laryngeal tumors [1]. Synovial sarcoma likewise represents a rare sarcoma histology of which only $3 \%$ arise in the head and neck [4]. We report the case of a young man with synovial sarcoma of the larynx.

\section{Case Report}

A 48-year-old man presented with a history of hoarseness of voice since 5 months, dyspnea since 3 months, and dysphagia since 2 months. He consulted an ENT surgeon where a fibre optic laryngoscopy showed a pedunculated mass occupying the laryngeal inlet and extending up to base of tongue (Figure 1). A computed tomogram (CT) showed a well-defined heterogeneously enhancing lesion, $2.7 \times 2.0 \times$ $2.6 \mathrm{~cm}$ in the laryngeal inlet in the supraglottic compartment, almost filling it (Figures 2(a), 2(b), and 3). Small cervical lymph nodes were present bilaterally. Patient underwent excision of the mass and tracheostomy. Intraoperatively, a globular pedunculated mass attached to posterior pharyngeal wall and arytenoids was seen. Histopathology examination of the biopsy specimen showed spindle cell sarcoma with hemangiopericytic pattern of intermediate grade, which on immunohistochemistry (IHC) was focally positive for cytokeratin and $\mathrm{Bcl} 2$ (Figures 4, 5(a), and 5(b)). A diagnosis of synovial sarcoma was made. His haemogram, serum chemistries, and CT scan of chest were normal. He was given postoperative external beam irradiation $60 \mathrm{~Gy} / 30 \#$. No chemotherapy was given since it was an intermediate grade tumor. The patient is alive in remission at 36 months.

\section{Discussion}

Laryngeal synovial sarcoma is an extremely rare form of laryngeal malignancy with less than 20 cases reported in the literature (Table 1 [5-23]). Synovial sarcoma is an aggressive malignant soft tissue tumor that is thought to arise from pluripotent mesenchymal cells and usually involve the lower extremities [24]. Sarcomas occur uncommonly in the head and neck region in adults and synovial sarcoma is extremely rare in this site. Squamous cell carcinoma accounts for over 


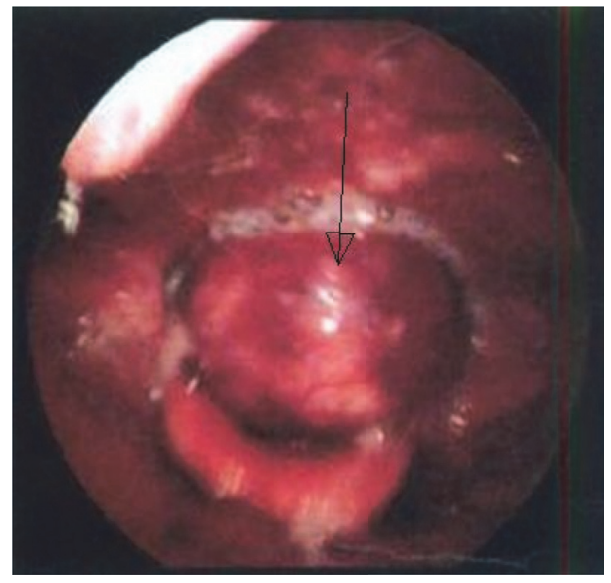

FIGURE 1: Laryngoscopy showing a pedunculated mass coming from laryngeal inlet.



(a)



(b)

FIGURE 2: (a) Plain CT scan of the neck showing soft tissue mass at the region of epiglottis with tiny specks of calcifications in the periphery. (b) Postcontrast image showing heterogenous enhancement.

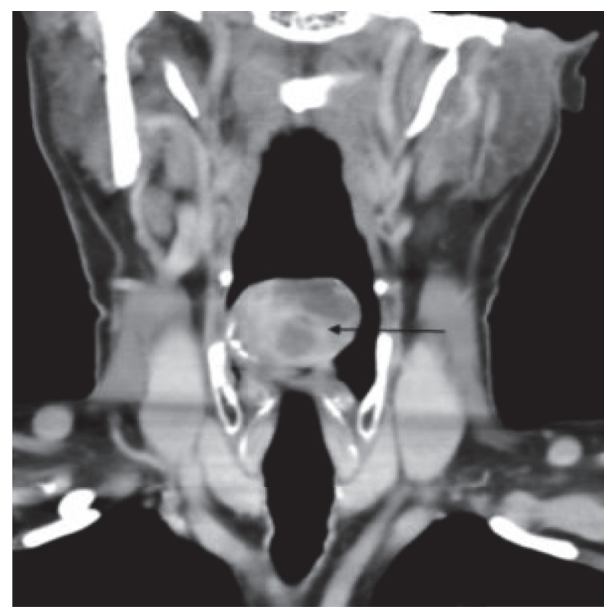

FIGURE 3: Coronal postcontrast image showing the mass lesion with nonenhancing areas. 


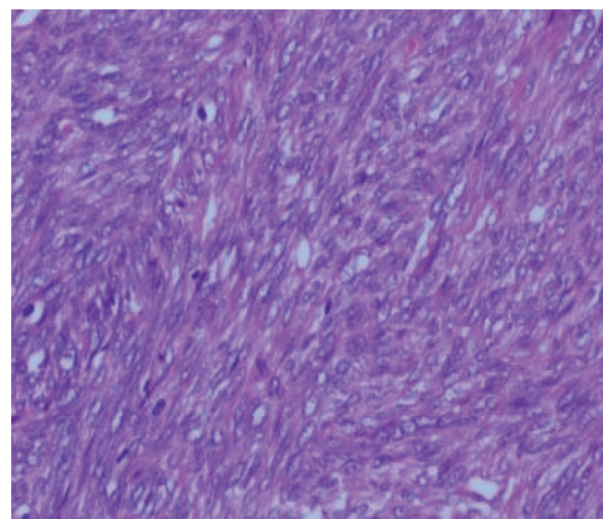

FIGURE 4: H\&E $\times 40$ showing spindle cell sarcoma with hemangiopericytic pattern.

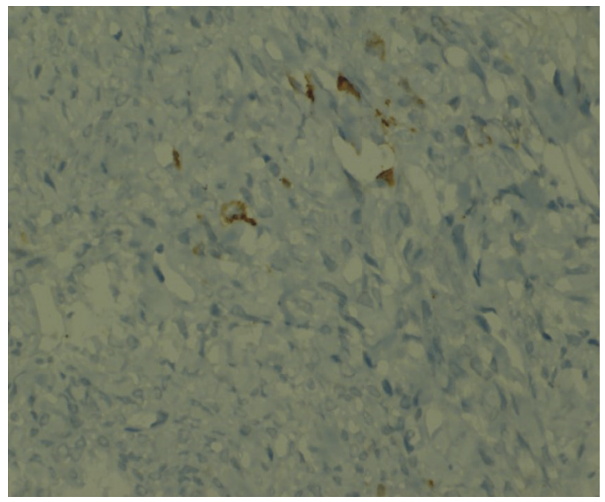

(a)

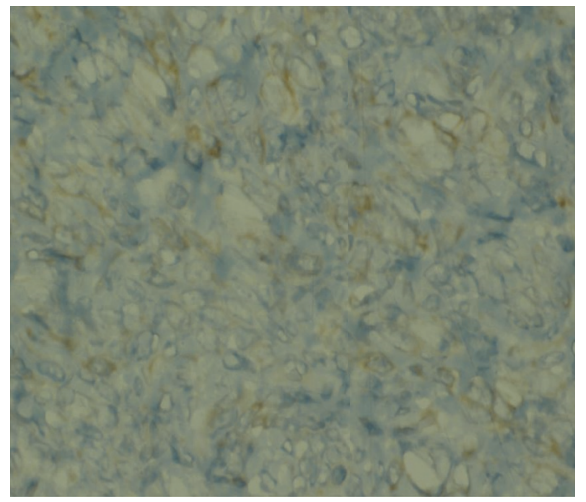

(b)

Figure 5: (a) Section showing focal positivity for cytokeratin. (b) Section showing focal positivity for Bcl 2.

$90 \%$ of all laryngeal cancers [24]. The median age of patients at diagnosis of the disease is the third decade of life and there is male predominance [25].

Sarcoma of the head and neck commonly presents as painless submucosal or subcutaneous mass and symptoms vary according to the location. Similar to primary squamous cell carcinomas of the larynx, sarcomas in this location produce symptoms secondary to mechanical interference with function dependent on the size. Hoarseness is usually the first symptom; stridor and dyspnea occur subsequently. Dysphagia usually occurs only when the tumor becomes large enough and protrudes into the hypopharynx [26]. In majority of the reported cases the gross appearance has been polypoidal and sometimes infiltrative. Ulceration is rare, in contrast with the early ulceration commonly present in carcinoma of the larynx. Sarcomas may originate in any part of the larynx but most often involve the vocal cords $[3,26]$. Our patient also had a similar presentation.

Synovial sarcoma acquired its name due to its microscopic resemblance to developing synovium but is immunophenotypically and ultrastructurally distinct from normal synovium, only rarely arising in joint cavities, and usually occurs in association with para-articular regions of the extremities, with no relation to synovial structures [27].
Histologically, the 2 predominant forms are biphasic and monophasic forms. A branching hemangiopericytoma-like vascular pattern is characteristic and a common finding in both types is the presence of stromal calcification, which ranges from focal to extensive and is an important diagnostic clue [28]. Immunohistochemically, synovial sarcoma is characterised by coexpression of mesenchymal and epithelial markers (cytokeratins and epithelial membrane antigen) [11]. $90 \%$ of synovial sarcomas harbour a specific translocation between the SYT gene on chromosome 18 and either the SSX1 or SSX2 gene on the X chromosome [24]. The type of fusion product correlates with the histological pattern; those with SYT-SSX1 are usually biphasic and those with SYTSSX2 are monophasic. Genetic testing is particularly useful in the poorly differentiated tumors. Our case was positive for cytokeratin and $\mathrm{Bcl} 2$.

The optimal treatment of synovial sarcoma is multimodal. The treatment for sarcoma of the larynx depends on its size, location, and grade. Radical surgical excision is generally accepted as the mainstay of therapy. Because most of the patients can be diagnosed early, conservative surgery with laryngeal preservation is usually possible. Radiotherapy (RT) is an important adjunct in the treatment of soft tissue sarcoma to diminish the incidence of local recurrence [29]. 
TABLE 1: Review of literature of synovial sarcoma of larynx.

\begin{tabular}{|c|c|c|c|c|c|}
\hline Sl.lno & Reference & Age/sex & Site & Treatment & Survival status \\
\hline 1 & {$[5]$} & $28 \mathrm{~F}$ & $\begin{array}{l}\text { Left hemilarynx } \\
\text { hypopharynx }\end{array}$ & $\begin{array}{c}\text { Pharyngolaryngectomy, } 1 \\
\text { year lung metastasis, XRT + } \\
\text { chemo }\end{array}$ & 2.5 years DIED \\
\hline 2 & {$[6]$} & $23 \mathrm{~F}$ & $\begin{array}{l}\text { Interarytenoid and } \\
\text { left arytenoid area }\end{array}$ & $\begin{array}{c}\text { Supraglottic laryngectomy } \\
\text { and total } \\
\text { laryngopharyngectomy }\end{array}$ & 12 years NED \\
\hline 3 & {$[7]$} & $76 \mathrm{M}$ & Rt supraglottic area & Laryngectomy & 3 years NED \\
\hline 4 & {$[8]$} & $28 \mathrm{~F}$ & $\begin{array}{l}\text { Rt aryepiglottic } \\
\text { fold } \\
\end{array}$ & Tumorectomy + XRT & 3 years NED \\
\hline 5 & {$[9]$} & $28 \mathrm{M}$ & Supraglottis & $\begin{array}{c}\text { Supraglottic laryngectomy } \\
\text { + RtND + XRT }\end{array}$ & 16 years NED \\
\hline 6 & {$[10]$} & $14 \mathrm{M}$ & Left arytenoid & $\begin{array}{l}\text { Excision tumor, local } \\
\text { recurrence at } 3 \text { years, total } \\
\text { laryngectomy + CT + XRT }\end{array}$ & $10 \mathrm{~m}$ NED \\
\hline 7 & {$[11]$} & $27 \mathrm{M}$ & Supraglottis & $\begin{array}{c}\text { Surgery, local recurrence } \\
3 \mathrm{~m}, \mathrm{CT}+\mathrm{XRT}, 3 \mathrm{~m} \\
\text { hemilaryngectomy }\end{array}$ & $9 \mathrm{~m}$ NED \\
\hline 8 & {$[12]$} & $68 \mathrm{~F}$ & Cricoids & $\begin{array}{c}\text { Laryngopharyngectomy }+ \\
\text { neck dissection, cervical } \\
\text { oesophagectomy }\end{array}$ & NA \\
\hline 9 & {$[13]$} & $24 \mathrm{M}$ & Supraglottis & $\begin{array}{l}\text { Hemilaryngectomy, } \\
\text { recurrence at } 12 \mathrm{~m} \text {, total } \\
\text { laryngectomy + XRT, lung } \\
\text { mets, chemotherapy }\end{array}$ & $42 \mathrm{~m}$ NED \\
\hline 10 & {$[14]$} & $16 \mathrm{M}$ & Supraglottis & $\mathrm{CO}_{2}$ laser surgery $+\mathrm{XRT}$ & $24 \mathrm{~m}$ NED \\
\hline 11 & {$[15]$} & $54 \mathrm{M}$ & Supraglottis & $\begin{array}{l}\text { Laryngopharyngectomy }+ \\
\text { modified neck dissection }\end{array}$ & $24 \mathrm{~m} \mathrm{NED}$ \\
\hline 12 & {$[16]$} & NA & $\begin{array}{l}\text { Rt aryepiglottic } \\
\text { fold } \\
\end{array}$ & $\mathrm{CO}_{2}$ laser surgery & $36 \mathrm{~m}$ NED \\
\hline 13 & {$[17]$} & $26 \mathrm{M}$ & Supraglottis & $\mathrm{CO}_{2}$ laser surgery & NA \\
\hline 14 & {$[18]$} & $79 \mathrm{M}$ & Supraglottis & Total laryngectomy & $3 \mathrm{~m}$ NED \\
\hline 15 & {$[19]$} & $57 \mathrm{M}$ & Supraglottis & $\mathrm{CO}_{2}$ laser surgery & $14 \mathrm{~m}$ NED \\
\hline 16 & {$[20]$} & $12 \mathrm{M}$ & Supraglottis & Surgery + chemo & $4 \mathrm{~m} \mathrm{NED}$ \\
\hline 17 & {$[21]$} & $26 \mathrm{M}$ & Larynx & Surgery + XRT & $20 \mathrm{~m}$ NED \\
\hline 18 & [22] & $37 \mathrm{M}$ & Supraglottis & Surgery + XRT + chemo & $41 \mathrm{~m}$ DIED \\
\hline 19 & {$[23]$} & $20 \mathrm{M}$ & Supraglottic larynx & $\begin{array}{l}\text { Total laryngectomy, left } \\
\text { hemithyroidectomy, left } \\
\text { modified radical neck } \\
\text { dissection + XRT + } \\
\text { chemotherapy }\end{array}$ & $18 \mathrm{~m}$ NED \\
\hline 20 & Present case & $48 \mathrm{M}$ & Supraglottic larynx & Surgery + XRT & $36 \mathrm{~m}$ NED \\
\hline
\end{tabular}

The major indications for postoperative RT are high grade lesions, positive surgical margins, larger tumor $(>5 \mathrm{~cm})$, and recurrent lesions [30]. Our patient received postoperative RT.

Adjuvant chemotherapy has been utilized for high grade synovial sarcoma. Doxorubicin and ifosfamide have been shown to demonstrate improvement in disease specific survival in the treatment of soft tissue sarcomas [31, 32]. Our patient was not given chemotherapy since it was an intermediate grade lesion. Disease recurrence is a significant problem, with up to $45 \%$ of patients with head and neck synovial sarcoma developing a local recurrence and 33\% developing distant metastatic disease [33]. Liu et al. in their review on treatment results of sarcoma of the larynx reported that the 5-year OS of patients with soft tissue sarcoma of the head and neck ranged from $32 \%$ to $75 \%$ [34]. Our literature review on 20 patients with synovial sarcoma of larynx shows that the survival of these patents ranged from 3 months to 16 years, with $50 \%$ alive at 2 years.

In summary, synovial sarcoma of larynx is a rare entity. Surgery is the mainstay of treatment with conservative surgery and organ preservation considered for early cases. Postoperative radiation is reserved for those with positive 
margins and high grade tumors and chemotherapy for high grade tumors.

\section{Competing Interests}

There is no conflict of interests or any financial disclosures.

\section{Authors' Contributions}

All authors have read and approved the manuscript.

\section{References}

[1] A. I. Farhood, S. I. Hajdu, M. H. Shiu, and E. W. Strong, "Soft tissue sarcomas of the head and neck in adults," The American Journal of Surgery, vol. 160, no. 4, pp. 365-369, 1990.

[2] R. A. Eeles, C. Fisher, R. P. A'pHern et al., "Head and neck sarcomas: prognostic factors and implications for treatment," British Journal of Cancer, vol. 68, pp. 201-207, 1993.

[3] S. G. Patel, A. R. Shaha, and J. P. Shah, "Soft tissue sarcomas of the head and neck: an update," American Journal of Otolaryngology-Head and Neck Medicine and Surgery, vol. 22, no. 1, pp. 2-18, 2001.

[4] S. Pai, R. F. Chinoy, S. A. Pradhan, A. K. D'cruz, S. V. Kane, and J. N. Yadav, "Head and neck synovial sarcomas," Journal of Surgical Oncology, vol. 54, no. 2, pp. 82-86, 1993.

[5] W. M. Gatti, C. C. G. Strom, and E. Orfei, "Synovial Sarcoma of the Laryngopharynx," Archives of Otolaryngology, vol. 101, no. 10, pp. 633-636, 1975.

[6] L. H. Miller, L. Santaella Latimer, and T. Miller, "Synovial sarcoma of the larynx," Transactions of the American Academy of Ophthalmology and Otolaryngology, vol. 80, no. 5, pp. 448-451, 1975.

[7] H. J. Quinn, "Synovial sarcoma of the larynx treated by partial laryngectomy," Laryngoscope, vol. 94, no. 9, pp. 1158-1161, 1984.

[8] M. Pruszczynski, J. J. Manni, and F. Smedts, "Endolaryngeal synovial sarcoma: case report with immunohistochemical studies," Head and Neck, vol. 11, no. 1, pp. 76-80, 1989.

[9] A. Ferlito and G. Caruso, "Endolaryngeal synovial sarcoma: an update on diagnosis and treatment," ORL, vol. 53, no. 2, pp. 116119, 1991.

[10] B. Morland, G. Cox, C. Randall, A. Ramsay, and M. Radford, "Synovial sarcoma of the larynx in a child: case report and histological appearances," Medical and Pediatric Oncology, vol. 23, no. 1, pp. 64-68, 1994.

[11] A. P. Dei Tos, R. Sciot, C. Giannini et al., "Synovial sarcoma of the larynx and hypopharynx," Annals of Otology, Rhinology and Laryngology, vol. 107, no. 12, pp. 1080-1085, 1998.

[12] S. M. Taylor, D. Ha, R. Elluru, S. El-Mofty, B. Haughey, and M. Wallace, "Synovial sarcoma of the pericricoidal soft tissue," Otolaryngology-Head and Neck Surgery, vol. 126, no. 4, pp. 428-429, 2002.

[13] B. Bilgic, Ö. Mete, A. S. Öztürk, M. Demiryont, N. Keles, and M. Basaran, "Synovial sarcoma: a rare tumor of larynx," Pathology and Oncology Research, vol. 9, no. 4, pp. 242-245, 2003.

[14] S. Papaspyrou, G. Kyriakides, and M. Tapis, "Endoscopic $\mathrm{CO} 2$ laser surgery for large synovial sarcoma of the larynx," Otolaryngology-Head and Neck Surgery, vol. 129, no. 6, pp. 630-631, 2003.
[15] K. Szuhai, J. Knijnenburg, M. Ijszenga et al., "Multicolor fluorescence in situ hybridization analysis of a synovial sarcoma of the larynx with a $\mathrm{t}(\mathrm{X} ; 18)(\mathrm{p} 11.2 ; \mathrm{q} 11.2)$ and trisomies 2 and 8," Cancer Genetics and Cytogenetics, vol. 153, pp. 48-52, 2004.

[16] V. Boniver, P. Moreau, and P. Lefebvre, "Synovial sarcoma of the larynx: case report and literature review," B-ENT, vol. 1, no. 1, pp. 47-51, 2005.

[17] H. A. Abou Zeid, S. A. Arab, A. M. Al-Ghamdi, A. A. Al-Qurain, and K. M. Mokhazy, "Airway management of a rare huge-size supraglottic mass," Saudi Medical Journal, vol. 27, no. 5, pp. 711713, 2006.

[18] P. Mhawech-Fauceglia, P. Ramzy, W. Bshara, S. Sait, and N. Rigual, "Synovial sarcoma of the larynx in a 79-year-old woman, confirmed by karyotyping and fluorescence in situ hybridization analysis," Annals of Diagnostic Pathology, vol. 11, no. 3, pp. 223-227, 2007.

[19] M. Capelli, G. Bertino, P. Morbini, M. Proh, C. E. Falco, and M. Benazzo, "CO2 laser in the treatment of laryngeal synovial sarcoma: a clinical case," Tumori, vol. 93, no. 3, pp. 296-299, 2007.

[20] M. J. Fernández-Aceñero, F. Larach, and C. Ortega-Fernández, "Non-epithelial lesions of the larynx: review of the 10-year experience in a tertiary Spanish hospital," Acta Oto-Laryngologica, vol. 129, no. 1, pp. 108-112, 2009.

[21] A. Al-Nemer and M. A. El-Shawarby, "Laryngeal synovial sarcoma: case report and literature review," Gulf Journal of Oncology, vol. 1, no. 9, pp. 52-56, 2011.

[22] Y.-Y. Bao, Q.-Y. Wang, S.-H. Zhou, K. Zhao, L.-X. Ruan, and H.-T. Yao, "Poor outcome of comprehensive therapy in a case of laryngeal synovial sarcoma," Radiology and Oncology, vol. 47, no. 2, pp. 111-118, 2013.

[23] C. Saxby, R. Bova, and M. Edwards, "Laryngeal synovial sarcoma: a rare clinical entity," Case Reports in Otolaryngology, vol. 2013, Article ID 578606, 4 pages, 2013.

[24] E. M. Sturgis and B. O. Potter, "Sarcomas of the head and neck region," Current Opinion in Oncology, vol. 15, no. 3, pp. 239-252, 2003.

[25] M. F. Okcu, M. Munsell, J. Treuner et al., "Synovial sarcoma of childhood and adolescence: a multicenter, multivariate analysis of outcome," Journal of Clinical Oncology, vol. 21, no. 8, pp. 16021611, 2003.

[26] H. L. Levine and R. Tubbs, "Nonsquamous neoplasms of the larynx," Otolaryngologic Clinics of North America, vol. 19, pp. 475-488, 1986.

[27] Enzinger and Weiss's, Soft Tissue Tumors, Mosby Elsevier, 5th edition, 2008.

[28] C. D. M. Fletcher, Diagnostic Histopathology of Tumors, Churchill Livingstone Elsevier, 3rd edition, 2007.

[29] Q.-T. X. Le, K. K. Fu, S. Kroll et al., "Prognostic factors in adult soft-tissue sarcomas of the head and neck," International Journal of Radiation Oncology Biology Physics, vol. 37, no. 5, pp. 975-984, 1997.

[30] P. K. Pellitteri, A. Ferlito, P. J. Bradley, A. R. Shaha, and A. Rinaldo, "Management of sarcomas of the head and neck in adults," Oral Oncology, vol. 39, no. 1, pp. 2-12, 2003.

[31] R. Lor Randall, K. L. S. Schabel, Y. Hitchcock, D. E. Joyner, and K. H. Albritton, "Diagnosis and management of synovial sarcoma," Current Treatment Options in Oncology, vol. 6, no. 6, pp. 449-459, 2005.

[32] J. F. Tierney, "Adjuvant chemotherapy for localised resectable soft-tissue sarcoma of adults: meta-analysis of individual data," The Lancet, vol. 350, no. 9092, pp. 1647-1654, 1997. 
[33] W. J. Harb, M. A. Luna, S. R. Patel, M. T. Ballo, D. B. Roberts, and E. M. Sturgis, "Survival in patients with synovial sarcoma of the head and neck: association with tumor location, size, and extension," Head and Neck, vol. 29, no. 8, pp. 731-740, 2007.

[34] C. Liu, M. Wang, W. Li, S. Chang, and P. Chu, "Sarcoma of the larynx: treatment results and literature review," Journal of the Chinese Medical Association, vol. 69, no. 3, pp. 120-124, 2006. 


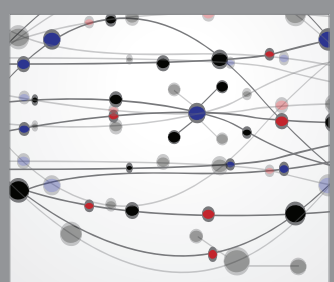

The Scientific World Journal
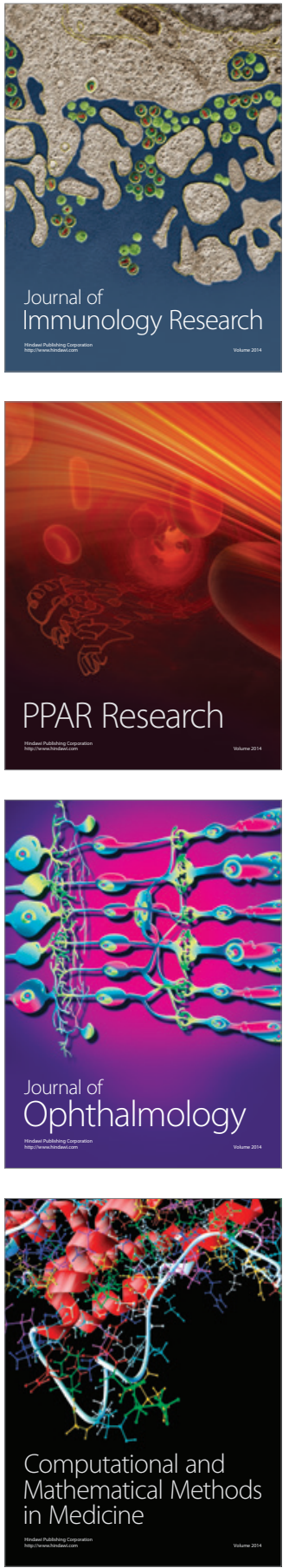

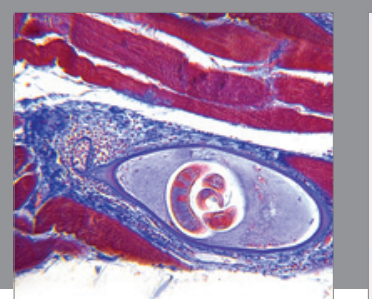

Gastroenterology Research and Practice
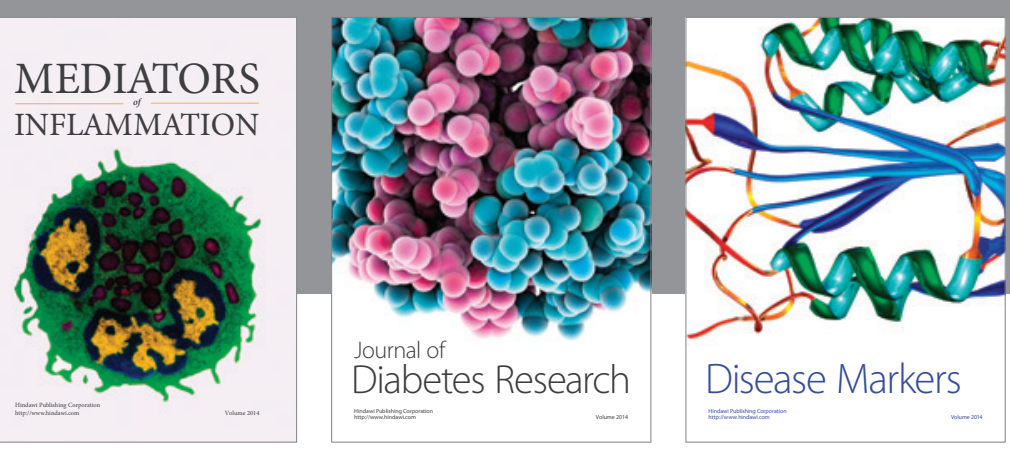

Disease Markers

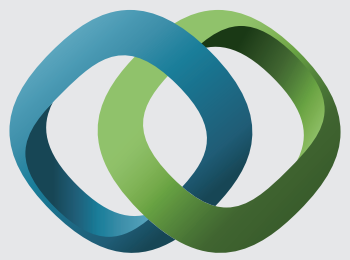

\section{Hindawi}

Submit your manuscripts at

https://www.hindawi.com
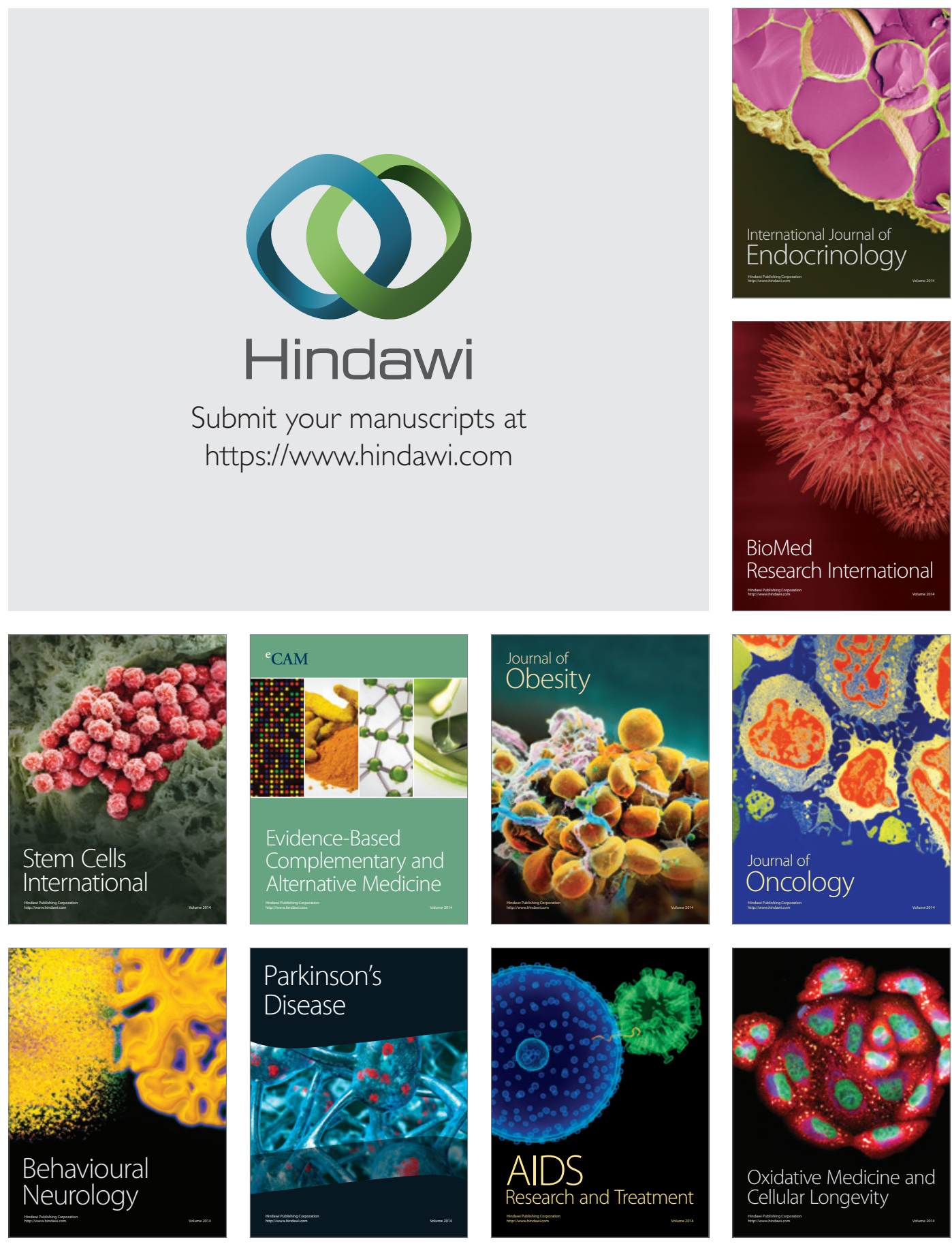